\title{
THE LIABILITY OF CORPORATION PROMOTERS TO ACCOUNT FOR PROFITS.
}

\section{(CONCLUDED.)}

III. The third class of cases is where the facts show an agency on the part of the person or persons making a profit by the transaction, which profit is incompatible with the capacity in which he or they acted. This arises either: (a) Where the owners of a property, as a factory or mine, call upon a financial agent to organize a corporation to purchase the property, agreeing that the corporation shall purchase for a given sum, out of which the vendor is to give the promoter a certain bonus, and the promoter represents to the proposed group that the property can be purchased for so much, naming, of course, the higher figure, and on the faith of his representation the corporation purchases. The situation is identical where the promoter represents to the owner that he can secure a corporation to purchase, and the agreement between the two is the same. (b) Where several parties agree to form a corporation and to purchase a property or properties and one of them acts as agent of the group to conduct the negotiations with the owner, and in so doing purchases it at one price and sells to his associates at a higher.

In either of these cases the party is more than a projector. $\mathrm{He}$ is a promoter in the sense that he is the agent of the company or corporation to be formed, and if he and the vendor by collusion agree that the vendor is nominally to sell to the corporation at a given price, while the actual price is a smaller sum, and the vendor is to turn over the difference to the agent, such conduct is a violation of the fiduciary relation in which the agent stands and is a fraud on the corporation. It is made to pay not more money than the vendor paid when he bought (that is immaterial and is analogous to Classes I and II supra) but it is made to pay more money than the vendor actually receives from it, 
and the difference is the secret profit of the promoter, which he has obtained by fraud, and for which he must account.

(A) The earliest example of (a) is Fawcett v. Whitehouse, I Rus. \& M. I32 (I829). There the owners of an iron-works lease, being desirous of sub-letting it, wrote to W., an investor, requesting him to form a syndicate to take over the lease, and offered him 12,000£ if he should succeed in so doing. W. did succeed in getting two others to join him in undertaking the same. On discovery by them of W.'s action they filed a bill praying that it be declared that the defendant received the $12,000 £$ on behalf of himself and the plaintiffs equally. Lord Lyndhurst held:

"When three persons are engaged in negotiating a partnership, and the negotiation is conducted by one as the agent of the other two, he should not, in my opinion, be allowed to make a private advantage for himself."

The most famous case of this type is Bagnall v. Carlton, 6 Ch. D. $37 x$ ( 1877 ). The plaintiffs were a joint stock company formed to purchase and operate a colliery belonging to the estate of $\mathrm{J}$. Bagnall, dec'd. The facts leading up to the formation of the company were as follows:

Before the company was formed J. Bagnall's trustees entered into negotiations with $\mathrm{R}$., a financial agent, to get up a company for the purchase of the property for about 300,000f. R. applied to C., and C. made an arrangement with G. upon the terms stated below. Two contemporaneous agreements were signed, by one of which the trustees of Bagnall's estate agreed to sell the property to a trustee for the company for $300,000 \AA$; and by the other, which was called the secret agreement, the trustees agreed with $\mathrm{C}$. that they would pay him 85,000 , which $\mathrm{C}$. in turn agreed to divide with $R$. and $G$. It did not appear that the vendors had any knowledge of the arrangement between C., G. and $R$., but thought that they were dealing simply with $C$. and $R$. The company was formed, $R$. supplying the directors. A prospectus was issued stating that a contract had been entered into on behalf of the company between the trustees 
of the Bagnall estate and a trustee for the company. No mention was made of the contemporaneous agreement. The purchase money, $300,000 £$, was paid to the Bagnall estate. $85,000 £$ was paid by the estate to $R$., who in turn gave $65,000 £$ to $G$. and $10,000 £$ to $C$. $R$. soon afterward became a director; $C$. and $G$. had no further connection with the company than above stated. The action was a bill by the company that the contract be set aside, and for the repayment of the sums received by the promoters, "except so much of the said sums as represented a fair remuneration for services rendered or expenses paid on behalf of the intended company." Before trial the bill was discontinued as to the rescission of the contract. It was held that the suppression in the prospectus of the agreement between the vendors and $C$. was unjustifiable and that the defendants R., C. and G. were in a fiduciary relation to the intended company, and, therefore, could not be allowed to retain any profit which they had made without disclosing it to the company. In the court below Bacon, V. C., at page $386-$ 387, said:

"One of the numerous grounds on which the defendants rely, and which may be said to be common to all of them, was that the vendors were at liberty to employ such agents as they thought fit to effect the sale, and to agree for and pay them such remuneration for their service by way of commission as they might determine; and that this was a matter which concerned only the vendors and their agents, and that none of them were in any sense blamable for not having disclosed the terms of a bargain which concerned only themselves. $* * *$ But although this may have a certain air of plausibility, and it might be true if the vendors and their agents were the only persons concerned in the transaction, it is wholly fallacious when applied to the facts of this case. It wholly omits the consideration that the employment of the agent was for the purpose of forming and of inducing other persons to subscribe in reliance upon a representation that was untrue; for it was not true, that the purchase money payable to the vendors was the sum mentioned in the prospectus, but it was the purchase money stated in the ostensible agreement, minus the amount to be paid by the vendors to their agents as a reward for procuring the subscription, and the nominal purchase money so diminished was the true sum which was to go into the pockets of the vendors."

At page $3^{85}$ he says, citing from the judgment of the 
Privy Council in Lindsay Petroleum Company v. Hurd, L. R. 5 P. C. 243 ( 1874 ):

"It is difficult to conceive any thing more clearly fraudulent than for the owners of a property to arm a person whom they know to be about to endeavor to find others to take up a purchase, whether as a company or otherwise, with a document purporting to be an offer made by themselves, as owners, to sell at a fictitious price, at which price he is to propose to other people to take up and accept that offer as if it were the real one. If that be not the real price which the owners of the property expect to get, and if they are parties to an arrangement that the intermediate agent, who is to induce others to accept the offer, is himself to put a considerable part of the nominal price into his own pocket, without any communication of the facts, the document is a dishonest and false document on the face of it."

On appeal the judgment below was affirmed, Cotton, L. J., saying at page 407 :

"When once persons, who have got a contract for a company intended to be formed, do put forward to the public an option to join in the company and to take the purchase, then from the very time when the contract is entered into they make themselves trustees for the company, and are, as regards obtaining any secret profit for themselves in the same position as if the company accepted it at the time when the contract was entered into."

The difference between this case and Gover's case is obvious. In this case C. et al. never bought the property for themselves, but they first agreed with the owner to sell it for him to a company to be formed; then they represented to the public, who were invited through the prospectus to join the company, that the property could be purchased from the owner at a given sum, and they made a contract to that effect with one acting for the company, whereas, in fact, the owner actually sold for a sum less by $85,000 £$ than the prospectus stated, and the defendants pocketed the difference. In Gover's case, M. (the projector) bought from the owner for himself. It is true that part payment was to be made in the stock of the company later to be formed to work the patent purchased, but $M$. was 'an out-and-out purchaser, and hence was a real vendor to the company. The company bought of him, knowing that it did so, and it was only from 
the time of the contract he negotiated with the trustee of the company that he became a promoter in a sense of having anything to do with the company. He was then the owner of a patent for which he had the undoubted right to get the best price possible. In Gover's case the public were asked to come in and purchase a property. In Bagnall v. Carlton the public were asked to come in and share the benefit of a bargain which was falsely represented.

This difference was long ago recognized in the case of Foss v. Harbottle, 2 Hare 46I (I843) where at page 489 the court says that where the public is invited to join in a project on a representation that the property has been acquired for the company, that is as an invitation to the public to participate in the benefit on the terms on which the projector had acquired it, but that if persons, though intending to form a company, should purchase land and state at once that they are the owners and purpose to sell it at such a price, they have a right to sell it as they see fit.

The difference between where there is no liability and where there is was pointed out by Justice Sharswood in Densmore v. Densmore Oil Company $64 \mathrm{~Pa} .43$ ( 1870 ). In that case the defendants owned oil lands and leases, which they had acquired with no idea of sale, or of forming a corporation. Later they came to Philadelphia and consulted Lawrence. another defendant, as to the best way to sell the property. It was then agreed that a corporation should be formed, to be capitalized at $\$ 500,000$, and that Densmore and his associates should receive $\$ 122,500$ in cash and 16,000 shares of stock; 9,500 shares were to be delivered to Lawrence and his associates for promoting the corporation. The corporation was then organized, and $\$ 122,500$ paid to the defendants in cash. The 9,500 shares were transferred to Lawrence, et al., who subscribed to no portion of the stock, and received only the above Densmore stock. Justice Sharswood said at page 49:

"There are two principles applicable to all partnerships or associations for a common purpose of trade or business, which appear to be well settled on reason and authority. 
"The first is, that any man or number of men, who are the owners of any kind of property, real or personal, may form a partnership or association with others, and sell that property to the association at any price which may be agreed upon between them, no matter what it may have originally cost, provided there be no fraudulent misrepresentations made by the vendors to their associates. They are not bound to disclose the profit which they may realize by the transaction. They were in no sense agents or trustees in the original purchase, and it follows that there is no confidential relation between the parties, which affects them with any trust. It is like any other case of vendor and vendee. They deal at arms' length. Their partners are in no better position than strangers. They must exercise their own judgment as to the value of what they buy. $* * *$

"The second principle is, that where persons form such an association, or begin or start the project of one, from that time they do stand in a confidential relation to each other, and to all others who. may subsequently become members or subscribers, and it is not competent for any of them to purchase property for the purposes of such a company, and then sell it at an advance without a full disclosure of the facts. They must account to the company for the profit, because it legitimately is theirs. It is a familiar principle of the law of partnership, that one partner cannot buy and sell to the partnership at a profit, nor if a partnership is a contemplation merely, can he purchase with a view to a future sale, without accounting for the profit. Within the scope of the partnership business, each associate is the general agent of the others, and he cannot divest himself of that character without their knowledge and consent."

The sentence: "They were in no sense agents or trustees in the original purchase, and it follows that there is no confidential relation between the parties, which affects them with any trust," is criticised by Mr. Taylor in his "Treatise on Private Corporations," 5th Edition, $\$ 83$, at page 56 , in that he says that it implies that the promoter, not being affected with any trust, may sell at an unfair or exorbitant price. Doubtless all that Justice Sharswood meant was that the promoter is not affected with the trust, so as to prohibit him from selling at a profit, and therefore that he is free to resell at such a reasonable advance as he can contract for.

On another point, however, the Densmore case seems to be contrary to the cases mentioned under Class III A, in that the court did not consider Lawrence and his associates liable to refund the stock which was given them by Dens- 
more as a remuneration for their services. On page 52 the court says:

"Mr. Lawrence and his associates did not subscribe for any stock. They did not appear, and were not held out as subscribers to those who made purchases from them. It is true, that after the company was organized, the stock which they were to receive from Densmore, Roudebush and Canfield, as a compensation for their services, was issued to them directly-not to the vendors, and by them transferred. But this was done by a special order, as is satisfactorily explained in the testimony of E. B. Schneider; ' I heard Mr. Densmore request Mr. Lawrence to have the Densmore stock, which he (Mr. Lawrence), Watson, Hugel and Whitney, were entitled to, issued direct to themselves, as he might not be here when the certificates would be ready. It has not been, and cannot be, controverted, that the stock which they received was part of that which, under the original terms of sale, Densmore, Roudebush and Canfield, were to have in payment of the purchase-money."

It being admitted that the stock they received was part of the stock paid to Densmore as a portion of the purchase money it would seem that Densmore received less than the corporation paid, the difference going to the promoters. This is exactly the state of facts which the court in Bagnall v. Carlton condemned, and therefore it would seem that the Densmore case is contrary to that case on this point.

So, too, Bagnall v. Carlton differs from the Erlanger case. In both those cases the defendants had actively promoted the corporations. They had issued the prospectuses, they had secured the directors, and they had dominated the policy of the company, but in the Erlanger case they were at liberty to sell to a corporation at the highest possible price since they were not the agents of another vendor representing to the corporation that it could purchase at such and such a price. It is true that in both cases the defendants made a profit by the transaction, but it is also true that in the Erlanger case at the time of buying the property they did not buy on behalf of a corporation either formed or to be formed. They admittedly bought to sell at a profit, and in both cases they created a corporation to buy of them. In the Erlanger case the contract with the provisional trustee of the corporation was but twenty days after the 
defendants had purchased the property. Similarly, in the Lagunas case the defendants as the "Lagunas Syndicate" held the property five years before they sold part of it to the "Lagunas Nitrate Company." In the Erlanger case, the vendors named the directors for the new corporation, while in the Lagunas case they made themselves the directors. In both cases the resale was at a profit. In the Erlanger case the contract was vitiated by the misrepresentations of the prospectus, but not by the fact that the vendors to the corporation had sold for more than they had bought. The decision of the House of Lords distinctly negatives any idea of that sort. In the Lagunas case no recovery was allowed, although the promoters had adimittedly made a profit. But where the promoters have assumed a status such as they did in the Bagnall case,-where, in short, they represented to prospective shareholders a falsehood,- they are under duty bound to refund to the corporation the difference between what they represented to be the purchase price and what it really was.

It should be noted that neither C. nor G. joined the company, nor did they at any time direct its policy. They were through with it after receiving their bonus from $R$. Their counsel accordingly argued that they were merely "external" promoters, and were paid for their services like an engineer or solicitor. The court did not view the matter in that light.

Emma Silver Mining Company v. Green, II Ch. D. 918 ( 1878 ) is on all fours with Bagnall v. Carlton. Lord Jessel said at page 933 :

"I do not think it necessary to understand equity law in order to be convinced that it is a fraud if you tell the public that a mine is to be sold by the vendors for a million of money, when in fact it was agreed to be sold for a million of money less $200,000 \pm$ to be retained by the real purchaser, the man who agreed that it should be sold to a company to be formed by himself."

Another authority of the same effect is The Emma Silver Mining Company v. Lewis, 4 C. P. D. 396 (I879).

Finally, in Gluckstein v. Barnes ( 1900 ), A. C. 240 (S. C. 
in re Olympia ( 1898 ), 2 Ch. I 53 ), the promoters represented to a company that they had purchased at $140,000 \AA$ and would sell to the company for I80,000£. In truth the purchase had cost them I20,000£. The action by the liquidator was to recover 20,000 . Lord Halsbury held:

"My Lords, in this case the single question is, whether four persons of whom the appellant is one can be permitted to retain the sums which have been retained from the company of which they were directors by fraudulent pretensions that they had paid 20,000 more in truth than they had paid for the property which they, as a syndicate, had bought by subscribing among themselves, and then sold it to themselves as directors of the company."

Here, again, the promoters were guilty of a wilful fraud by deceivingly representing the price for which the property could be purchased.

Other examples of this kind are:

Einery v. Parrott, 107 Mass. 95 (187I).

Lydney Iron Ore Co. v. Bird, 33 Ch. D. 85 (I886).

Chandler v. Bacon, 30 Fed. 538 (1887).

South Joplint Land Co. v. Case, 104 Mo. 572 (189r).

Yale Gas Stove Co. v. Wilcox, 64 Conn. Ior (1894).

Woodbury Hts. Land Co. v. Loudenslager, 55 N. J. E. (1896).

First Avenue Land Co. v. Hildebrand, 103 Wis. 530 (1899).

(B) The earliest example of $(b)$ is Hichens v. Congreve, I Rus. \& M. I50 (I829). It was a suit by the shareholders of a company, on behalf of themselves and all other shareholders except defendants. The bill alleged that the defendants originated the company to work a mineral property in Ireland; that it was proposed that the company purchase a lease; that the said defendants were selected to make the purchase; that they charged the company $25,000 £$ for it although they had bought it from the owner for ro,ooo $£$ and that they had divided the profit. The defendants' answer stated that they had purchased for 10,000£ before the company was in existence, at their own risk, and that the additional I5,000£ was a legitimate profit on the resale. They admitted, however, that the conveyance was direct from the original owner to the company, and cited a con- 
sideration of 25,000 . But they alleged that this was done with the concurrence of the original owner "merely to simplify the title." A motion was made that the defendants be ordered to pay into the court the $15,000 £$. Evidently the contention of the defendants that they had purchased before the existence of the company and at their own risk was not sustained by the evidence, for the report concludes that the Vice Chancellor made the order.

Another example of $(b)$ is McKay's case (In re Morvah Consols Tin Mining Co.), 2 Ch. D. I (1875). In that case M., as agent of a company to be formed, agreed to buy a mine from $\mathrm{H}$., the owner, for 100,000£ cash and one thousand $5 E$ shares. By a contemporaneous agreement $\mathrm{H}$. was then to turn over six hundred shares to $M$. The company was organized and registered, $M$. made secretary, and $H$. had six hundred shares transferred to $M$. On winding up, the liquidator applied for an order on $M$. to pay on the shares which were still in his name when the company was wound up, which were five hundred. It was held.

"All the benefit which the agent of the purchaser received under such circumstances from the vendor must be treated as received for the benefit of the purchaser $* * *$ and it does not matter whether it formed part of the original bargain or was a present for remuneration for services. That being so, it is clear that all shares transferred by $\mathrm{H}$. to $\mathrm{M}$., for which there was no other consideration than the benefit which $H$. derived from $M$. in the course of his agency, belonged to the company. The company is entitled to say to M. 'Either these shares ought never to have been in existence or else you hold them only as trustee for the company."

It was further held that the fact that the shares turned out to be worthless was immaterial, and the measure of recovery was the highest value of the shares transferred to him.

The difference between this kind of a case on the facts and one like Gover's case cannot be better illustrated than by stating that McKay's case was decided November 9 , I875, by the unanimous decision of Mellish, L. J., Brett, J., and James, L. J., while Gover's case was decided December I, I875, by Mellish, L. J., Brett, J., James, L. J., and Bram- 
well, B., the judges in Gover's case all agreeing that at the time the first purchase was made the purchaser did not occupy a fiduciary relation, though they differ on the construction of the section of the English Companies Act then before the court.

Another illustration of the same circumstances is the early case of Beck v. Kantorowicz, 3 K. \& J. 230 ( I857). In that case the prospectus stated that a contract had been entered into by the company for $126,000 £$, " including all preliminary expenses, and a premium to parties who incurred the risk and liability of the original purchase." This preliminary expense amounted to $39,000 £$ and it was represented that the remaining $86,000 £$ went to the vendor. As a matter of fact he sold for $66,000 £$ and the defendent pocketed the difference. V. C. Page Wood held that the defendant's secret profit was a fraud on his fellow promoters and on the company. As to the fellow promoters, the defendant was with them as a copartner. As to the company, the Vice Chancellor said that the original contract of $L$. stated such purchase to be for a society or company they intended to form.

If the promoters instead of purchasing for themselves, admittedly purchase for a corporation to be formed, and represent themselves as acting on behalf of such intended corporation, then by their own acts and declarations they are estopped from claiming that they purchased for themselves. This is what occurred in Simons v. The Vulcan Oil and Mining Company, 61 Pa. 202 (1869). In that case S. et al. by articles dated December 5 , I864, agreed to form a corporation. As early as November $I 7$ they had advertised, stating that the company was about to acquire oil lands from the original owners. Letters patent were issued on January I3, I865. In December, I864, and January, I865, the defendants acquired various lands, which they resold to the corporation at greatly advanced prices, though the deeds purported to be from the original owners at such prices. In fact the owners were paid much less.. The defendants. represented that the price paid them was the price demanded 
by the original owners. In the court below Judge Hare charged the jury as follows:

"The argument is, and certainly it is a fair argument, that if the representations of the defendants with regard to the ownership of the land were true, they could only be true in this: that Mr. Simons, in taking the title took it not for himself, but as a corporator in behalf of the company, and virtually stood in the position of an agent or trustee".

Judgment against the defendants was affirmed in the Supreme Court where Thompson, C. J., said at page 2I7:

"If in order to get up a company they represented themselves as having acted for the association to be formed, and proposed to sell at the same prices they paid, and their purchases were taken on these representations, and stockholders invested in a reliance upon them, it would be a fraud on the company, and all others interested to allow them to retain the large profits paid them by the company in ignorance of the true sums actually advanced."

A decision of the same day in the same court on similar facts is McElhenney's Appeal, 6I Pa. I88 (1869).

In cases $(A)$ the defendant is liable to refund on the ground that he has represented to the public that the corporation to be formed can purchase for a certain sum, whereas the vendor will actually receive a less sum. The gravamen of this is fraud, and it is academic whether one chooses to say that the promoter is the trustee of a future cestui corporation, or is the agent of the future incorporators. The defendant has made false representations, on belief of which the plaintiffs acted in forming the corporation, and if they are injured thereby they have a right to redress. As Bowen, J., says in Whaley Bridge Printing Company v. Green, 5 Q. B. D. Io9 (1879):

"In every case the relief granted must depend upon the establishment of such relations between the promoter and the birth, formation and floating of the company, as to render it contrary to good faith that the promoter should derive a secret profit from the promotion."

Therefore, it is submitted that the ground of recovery in such case is the fraudulent representation to the corpora- 
tion,-that, in short, the case does not differ from any ordinary claim for damages in an action of deceit.

In cases (B) no fiction of an implied trusteeship is necessary. The defendant is simply the agent of his fellows, and the elementary rule that an agent cannot make a secret profit at the expense of his principal applies. This is well stated by Lord Westbury in Tyrrell v. the Bank of London, Io H. L. C. 26 ( I862). That was a case where the defendant Tyrrell was a solicitor to purchase a property for the Bank of London and in the transaction secured for himself a profit from the vendor. Lord Westbury says at page 39:

- The principle is that the solicitor shall not be permitted to make a gain for himself at the expense of his client. The client is entitled to the full benefit of the best exertions of the solicitor. The relation of the solicitor and client involves the relation between principal and agent."

Or as Cotton, L. J., puts it in Ladyzuell Mining Company v. Brookes, 35 Ch. D. 400 (I887) at page $4 \mathrm{II}$ :

"If, in fact, they who purchased this mine had, before the time they made the purchase, invited the public to come in and join the company to work this mine, then it may well be that if the company was formed, and if they had handed over the mine to the company, the shareholders would have been entitled to say 'As you have formed a company to work this mine you must admit that the purchase was not made in your individual capacity, but was made for the purpose of offering it to the public, if they came in and formed a company to work it." "

If the facts in either cases A and B under Class III are present, disclosures to the directors and ratification by them of the secret profits may be of no avail against the defrauded shareholders. It is not within the power of the directors if they are the promoters themselves or persons collusively chosen by them to officially "whitewash" the illegal profits of the agent of the corporation, for they are but the representatives of the real owners, to wit, the shareholders, and they cannot betray their trust by passing a vote of approval on their own fraudulent acts. On this point Lord Jessel said in In re British Seamless Paper Box Company, I7 Ch. D. 467 (I88I) : 
"I quite agree to this, that if promoters make an agreement to get a profit for themselves out of what is apparently paid to the vendors, it is immaterial whether the contract with the vendor is approved by the directors of the company, who are the promoters, just before the allotment or just after, in both cases it is intended to cheat the future shareholders."

Lord Halsbury in Gluckstein v. Barnes, A. C. (I900) 240 observes on the same point:

"It is altogether absurd to suggest that a disclosure to the parties to this transaction is a disclosure to the company of which its directors were the proper guardians and trustees."

The Supreme Court of Pennsylvania held the same in Simons v. Vulcan Oil and Mining Company, 61 $\mathrm{Pa}$. St. 202 ( 1869 ).

But if the profits of the promoter, under Class III, are made known to the prospective corporation, if the promoter in short says: " $X$ has a property to sell. He wants roo,ooo£ for it, and I will get it for you, and organize you according to the requisites of the statutes, for I25,000£," then the profit is no longer secret and even though the promoter acts as agent of the corporation there is no deceit and he is entitled to retain his profit.* Thus, in Whaley Bridge Printing Company v. Green, 5 Q. B. D., Bowen, P., said at II2:

"There is in the first place nothing illegal in the contract that $S$. should receive $3,000 \pm$ out of the sale, provided it was not to be kept secret from the company when the company was induced to negotiate for the purpose. ***As soon as $\mathrm{S}$. and $\mathrm{G}$. formed the company and nominated its board, it became their duty, in my opinion, to inform the company of this private arrangement between them. Thereupon the company might either, at its option, decline the proposed purchase or accept it, claiming the benefit of S.'s bargain, or might, if they thought it reasonable sanction the agreement and allow S. to retain the profit himself."

In the case of In re Sale Hotel, 77 L. T. Reports 68I ( 1898 ) one $\mathrm{H}$. became one of the promoters of a company

* This is provided for in the English Companies Act of Igoo. See L. R. Statutes I900, p. IOI, section IO. I, (j). 
formed for the purchase of a hotel, the vendor of which offered 2,000f to him and the other promoters if they would form such a company. $H$. received $250 £$ of this amount to the knowledge of the other promoters, who became the directors, and the date and parties to the agreement under which he took this profit were stated in the prospectus issued to the public inviting share subscriptions. In a suit by the liquidator on the winding up of the company ,Wright, J., held that $\mathrm{H}$. was liable to refund. $\mathrm{He}$ said:

"I should be very unwilling to hold that a mere reference to an agreement by date or names, without any disclosure of the fact that it relates to benefits to be given to the promoters of a company can be held to be a sufficient disclosure. There seems to be no zuthority on this point, but so far as I am concerned, it seems plain that it is not the less a secret profit because an opportunity is given to a shareholder who chooses to take the trouble to find out what it is * * * That being so, there is no doubt that the profit here was a secret one, so far as the shareholders were concerned. It was not a secret one so far as the directors were concerned, but that can not help $\mathrm{H}$., because all of the directors were equally distributing among themselves the promotion money paid by the vendor."

On appeal the decision was reversed, in a rather unsatisfactory opinion by Lindley, M. R. He says, 78 L. T. Reports 370:

"Why the company should be informed who were to be paid by W. (the vendor) or what sums they were to be paid I cannot conceive, unless, indeed, the persons paid by him stood in some other relation to the company than promoters. Some persons paid by him were directors, and were bribed by him or his agent to become such, and the directors so bribed have very properly been held accountable to the company for the bribes so received. This was a very discreditable transaction, and $H$. is, in my opinion, shown to have known about it. But I fail to see how this gives the company any right to require $\mathrm{H}$. to pay over to it the $250 \pm$ paid to him.

It is rather difficult to understand what the Master of Rolls means by the first sentence above quoted, but the gist of the decision is that he thought the disclosure of profits a fair one, therein differing from the court below. There can be no doubt of the principle that if a promoter who 
stands in the fiduciary relation indicated by the cases under Class III endeavors to make a profit on the resale of the property to the corporation and that profit is fairly stated to those who are expected to become stockholders, either through the prospectus or in any other public manner, and the corporation, acting independently, adopts the contract and allows him the profit, he may retain it. The question in each case is a matter of fact as to what is a sufficient disclosure. As already pointed out, a disclosure to a board of directors who may be themselves the participants in the profit, or who are merely the figure-heads of those who are participating, is not sufficient, and the adoption of a resolution by them ratifying such profits is unavailing against the defrauded stockholders. It is to those who are invited to become the owners of the corporation that the disclosure must be made, and if they, acting as owners, see fit to allow their agent to profit by the transaction which he carried on for them, there can be no cause for complaint. This is pointed out in Simons v. Vulcan Oil and Smelting Company supra, at page 22I, when the court says:

"We do not doubt that if defendants had disclosed the exact sum at which they bought the lands, and had refused to sell for less than the sum which they eventually received, their right to hold the sums received would have been unimpeachable."

To the same effect in Short v. Stevenson, 63 Pa. St. 95 (1869).

Finally, in order that the corporation on discovery of an illegal secret profit may be in a position to recover it from the promoters, it need not rescind its contract with the original vendor. In Emma Silver Mining Company v. Lezeris, 4 C. P. D. 396 , the court says :

"It is, however, urged that the company have not rescinded their contract with $P$. (the vendor); that so long as that contract remains unrescinded the shares given by him to the defendants must be treated as having been his to give, and that the company cannot claim them. But the moment it is proved, as in this case it is, that the $1,000,00 \pm$ paid by the company, although nominally paid for the mine, was only colorably so; that some portion of that sum, say' $5,000 \pm$ was not for 
the mine at all as the company had supposed, but for something very different, *** it follows, in our opinion, that the company can recover from the defendants what they so obtained, without rescinding its contract with P."

To the same effect, also, are the cases of Lydney Company v. Bird, 33 C. D. 94, (I886), Yale Gas Stove Company v. Wilcox, 64 Conn. IOI (I894), and Hayward v. Leeson, I76 Mass. 322 (I900).

Or if the vendors are sued by the corporation as codefendants with the promoters, the corporation may compromise as to them without prejudicing its rights to continue against the promoters. This was the fact in Bagnall v. Carlton.

Other cases illustrating the general principle of Class III $(B)$ are:

Emery v. Parrott, I07 Mass. 95 (187r).

Dorris v. French, 4 Hun. 292 (1875).

Bosler v. Land Co., 89 Va. 455 (I892).

Dickerman v. Trust Co., 176 U. S. I8I (1899).

Humbird v. Davis, 210 Pa. $31 \mathrm{I}$ (1904).

Short v. Stevenson, $63 \mathrm{~Pa} .95$ (1869).

Burns v. McCabe, $72 \mathrm{~Pa} .309$ (1872).

Yeaney v. Keck, 183 Pa. 532 (1898).

The last three cases were by individual plaintiffs to recover their subscriptions on the ground of fraud.

IV. Promotership does not necessarily cease upon the incorporation of a company. It is a common error to imagine that after a company is duly incorporated its directors are the only persons who stand in a fiduciary relation to it. A person not a director may still be the promoter of a company already incorporated, but whose capital is not yet sufficiently taken up, and it therefore still needs the service of a promoter. Therefore, the fourth class of cases arises where promoters after incorporation, and while they still control the company, vote to themselves blocks of stock as an alleged remuneration for their services, which vote is not disclosed in the prospectus of the corporation or otherwise. Haywood v. Leeson, I76 Mass. 310 (I900), Brewster v. Hatch, I22 N. Y. 349 ( I890). In the case of Haywood v. Leeson the promoters before any capital stock had been 
issued to the public caused to be issued to themselves, as a remuneration for their services as such promoters, by the vote of all the persons who then had any interest in the corporation, being none but themselves, one-third of the whole capital stock. The prospectus instead of disclosing the above fact, stated that " over one-half million dollars of its capital were subscribed before the company's organization, at par." The prospectus invited subscriptions to the balance of the stock. On a bill filed by the Receiver the court held that:

"It is a fraud for promoters to undertake to decide for the stockholders in the corporation to be organized that one-third of the whole capital stock is a fair remuneration for their services as promoters, to issue one-third of the capital stock to themselves as such remuneration, and then to invite the public to subscribe to the stock of the corporation, without disclosing that fact to the subscribers and getting their consent to the payment of that remuneration."

The court cites a large number of English cases, all of which fall under Class III supra. The court uses this further language:

"It is to the stockholders that the promoters must make the disclosure of the remuneration which is, or is to be, paid to them, and it is the consent of the future stockholders that must be obtained to make that payment valid."

This language is too general in that it does not limit the future stockholders to whom the disclosure must be made, for if taken literally it might well include any one who, at any time, however remote, becomes a stockholder. Obviously the court did not mean that, for a little further on in the opinion it says :

"Promoters can make the necessary disclosure of the remuneration they stipulated for by including in the prospectus a full statement thereof. If such a statement is not made therein, they cannot honestly take any remuneration for promoters' services, unless it is voted by the stockholders after the capital stock has been taken by the public."

Evidently what the court means is that the disclosure must be made to those who are the first bona fide takers of the stock. 
The division of the shares in Hayzeod v. Leeson, nominally as remuneration of the services, was merely a variation of the somewhat common system of allotting shares to promoters gratuitously. That such a transaction cannot. stand as against the corporation creditors is self-evident. Society for the Illustration of Practical Knowledge v. Abbott, 2 Beav. 559 (I840).

So also the directors of a corporation cannot allot to themselves a number of shares gratuitously or at an undervalue. Shaw v. Holland, 2 Ch. 305 ( I90I).

But if, on the other hand, the promoters transfer property, as a mine which they have been working for themselves, and receive a majority of the shares as consideration, the mere fact that it later turned out that the property was actually of much less value than had been supposed, is no ground on which creditors can recover alleged unpaid subscriptions, if at the time of incorporation there was no fraud or misrepresentation, and the award of shares to the promoters was believed by all parties to be a fair and honest price for the property transferred. On such facts in Young v. Erie Iron Company, 65 Mich. I I (I887) the court said:

"It must be considered as well settled that corporations cannot agree among themselves that property worth only $\$ 80,000$ shall be treated as worth $\$ 422,000$, and count, at that sum, as so much capital paid in, and then proceed to make their shares as fully paid up and non-assessable upon such false basis, as such action would be clearly a fraud upon the creditors. But it is equally well settled that such corporations are not responsible for an honest error of judgment, or a mistake in placing a valuation upon property appropriated or used as capital by a manufacturing or mining company."

Similar to Hayzwood v. Leeson and Shaw v. Holland is the case where a director receives a number of paid-up shares from the promoter, sometimes necessary by law in order to qualify him as a director, but in all events as a gratuity, and the director then votes to carry out a provisional contract between the corporation and the promoter. On such facts the director is liable for the value of the shares. Pearson's case, 5 Ch. D. 336 ( 1877 ) the Phosphate Servage Company v. Hartman, id. 394 ( 1877 ), Bland's case, 2 Ch. 6і 2 
(I893), Nant-y-glo and Blania Iron Works Co. v. Grave, I2 Ch. D. 738 (1878), and in re the Fitzroy Bessemer Steel Co., 50 L. J. n. s. I44( 1884 ).

V. Lastly, it is but a gradation from Classes III and IV to Class V, where the admitted agent of a corporation already in existence purchases as agent and sells to the corporation at a higher price.

It is scarcely necessary to dwell on this point further than to mention it as being the last state of facts which rounds out the classes before referred to. The fundamental rules of the law of principal and agent apply, and a few citations are sufficient to support the proposition that such profit is illegal and may be recovered back by the defrauded principal. The Great Luxembourg Railway v. Magnay', 25 Beav. 586 ( 1858 ) was a case which went off on another point, but Romilly, M. R., puts it this way:

"If, as in the case of The Midland Railzuay Company v. Hudson (not reported), a director of a railway company entered into a contract for the purchase of a large quantity of iron in the shape of rails but before it is wanted and before it has been actually delivered the price of iron should happen to rise, the trustee is not at liberty to put into his pockets the difference between the market price of the iron when purchased and that when delivered. He cannot, in fact, sell it again to the company as if it were his own property. The whole benefit must go to the shareholders."

To the same effect are:

Dunne v. English, L. R. I8 Equity 523 (1874).

Liquidators of Imperial Mercantile Credit Association v. Coleman, L. R. 6 H. L. 189 ( 1873 ).

Archer's case, I Ch. 322 (I892).

Bland's case, 2 Ch. 612 (1893).

Costa Rica Ry. Co. v. Forwood, I Ch. 746 (Igor).

Parker v. Nickerson, I37 Mass. 487 (1884).

Pittsburg Mining Co. v. Spooner, 74 Wis. 307 (1889).

Fountain Spring Park Co. v. Roberts, 92 Wis. 345 (1896).

These cases are often cited in connection with the Erlanger case supra, but it is submitted that a careful examination will show the distinction between that case and these latter cases, which it is here attempted to point out. 
In most of these cases the entire transaction took place after incorporation,-i.e., a director or other member made the profit at the expense of the corporation by selling to it property at a profit which he purchased as the corporation's agent. Generally such a person was one who had been a promoter, and consequently the courts have supported their decisions by generic references to the fiduciary relation existing between promoters and the corporation. This is unnecessary, since the defendant is liable, not because he has been a promoter, but because at the time of the sale he is the agent of an existing corporation, acting as its representative. and, of course, cannot profit at its expense.

THE MEASURE OF DAMAGES.

I. Where promoters, acting in a fiduciary capacity, purchase at a price and sell at a higher. The measure of clamages is the profit obtained.

Simons v. Vulcan Oil \& Mining Co., 6r Pa. St. 202 (1869).

Burbank v. Dennis, 10I Cala. 90 (1894).

Gluckstein v. Barnes, A. C. 240 (1900).

In re Leeds \& Hanley Theatre of Varieties, $\mathrm{I}$ Ch. 809 (Ig02).

2. Where promoters receive a cash bonus from the real vendor, the measure is the amount of such bonus.

Bagnall v. Carlton, 6 Ch. D. $37 \mathrm{I}$ (I877).

Lindley Iron Ore Co. v. Bird, 33 Ch. D. 85 (I886).

And that, irrespective of the actual value of the property, Yale Gas Stove Co., v. Wilcox, 64 Con. xor (1894).

3. Where promoters receive their illegal profits in stock. It was held in McKay's case, 2 Ch. D. I ( 1875 ) that defendant should be ordered to pay the largest amount of damages which could at any time have been incurred, and that was taken to be the par value of the shares, the court saying:

\footnotetext{
"It may be assumed that they might have been allotted to a solvent holder."
} 
In a case where they received stock and immediately sold it, the damages were held to be the amount received.

Emma Silver Mining Co. v. Lewis, 4 C. P. D. 396 (1879).

In Yeiser v. United States Board and Paper Co., ro 7 Fed. 340 (IgOI) it was ordered that the stock allotted to defendant promoters be cancelled.

Of course, the existence of such illegal profits, whether in cash or stock, is sufficient cause for rescinding the purchase on the part of the corporation, provided the action is taken in time.

Cortes Co. v. Thannhauser, 45 Fed. 730 (1891).

Burbank v. Dennis, Ior Cala. 90 (I894).

4. Where directors receive shares gratuitously, either from promoters, or by their own distribution, it was held in several English cases, following McKay's case, that the defendants were liable for the highest value the shares reached while in their possession.

Pearson's case 5 Ch. D. 336 (1877).

Nant-y-glo and Blania Iron Works Co. v. Grave, I2 Ch. D. 738 (1878).

Mitcalfe's case, $\mathrm{x}_{3}$ Ch. D. I69 (1879).

On the other hand, in In re The Fitzroy Bessemer Steei Co., 50 L. T. n. s. I44 (I884) the court held without discussion that the defendant was liable for the market value of the shares at the time he received them ( $3 \mathfrak{f}$ on rof shares), and that without interest, as no dividend was ever declared. This was followed in Shaw v. Holland, 2 Ch. 305 (1900) Rigby, L. J., at page 3 I I says :

"There remains the question as to the date at which the damage should be liquidated. I agree with the rule that a wrong-doing director ought to be made liable for any property of the company (such as shares) which has come into his hands wrongfully and is retained by him, and that it ought to be fixed at the highest price which the shares ever attained while in his hands. But we must not erect that rule into an absolute principle of law, and say, if evidence is given of the sale of some shares at such a price during the period in question it must be assumed that all the shares of the company, including those 
lield wrongfully by the directors, might have been sold at that price; that would be going too far. You must consider the circumstances of the particular case and I am not disposed to differ from the finding of the learned judge that it had not been shown that the company could have ever obtained in respect of all the shares wrongfully held by the defendants the full price which was obtained in the market for some shares on a particular day. The number of shares held by the defendant was very large, and the throwing upon the market at any one time of all those shares might have influenced very greatly the price and brought it down considerably."

Collins, L. J., held the same, likening the allotment to conversion at the common law, and hence holding that the measure of damages was the value of the shares at the time of conversion, and not the highest value which they happened to reach in the fluctuations of the market.

In Haywood v. Leeson, I76 Mass. 3 IO (Igoo) it was said that ordinarily damages were assessed as of date of taking (thus in accord with Shaw v. Holland), but when the property had no value at that time, as it was stock of a corporation not jet launched, the date should be carried forward to the date when the value of the stock was fixed.

5. Where a large majority of the shareholders of a defunct corporation have agreed to a reorganization, and have signed an agreement releasing all claims arising from the misconduct of the promoters and directors in taking illegal profits, dissenting minority shareholders can recover only a proportionate amount.

Spanlding v. Town Site Company, 106 Wis. 48I (1900).

In conclusion, the point of prime importance to be determined in every case is the exact time, as nearly as can be ascertained, when any person begins to act as a promoter, and hence presumably in the interests of a corporation to be organized.

It is clear, on the one hand, that that time may antedate the legal birth of the corporation by the granting of a charter by the State. In fact, that is usually the case. On the other hand, the purchase of property with intent to resell to a corporation is not sufficient. Nor does subsequent 
promotion relate back, so as to cast a fiduciary relation over the original purchase. There must be something done by the party so that he no longer acts independently but as the representative of others. This may be by his stating that he so acts, or by inducing others to trust in his representations which are false, or by any other of the various ways illustrated by the cases. But the mere fact that a man sells property at a profit to a corporation of his own promotion is not ipso facto sufficient to render him liable to account. It must be shown that at the time he purchased the property he occupied such a relation to the corporation that any retention of profits by him is contrary to good faith. ${ }^{1}$

Boyd Lee Spahr.

\footnotetext{
${ }^{1}$ The English Companies Act of 1900 (L. R. Statutes, Vol. xxxviii, I900, page I00) exhaustively directs what every prospectus shall contain. The Companies Act of I890 (L. R. Statutes, Vol. xxvii (I890), page ${ }^{1} 6$ ), cited as the Director's Liability Act, regulates the liability of company directors to defrauded investors.
} 